\title{
Clinical Profiles Of Frostbite In University Airlangga Teaching Hospital Surabaya - A Case Report
}

Thomas Eduardus Sudrajat Wahyu Nugroho

Beta Subakti Nata'atmadja
Background: We report 3 adults who suffered frostbite of the hand and face following Mount Denali Expedition (6192 meters above sea level). The patients get rewarming and analgetics as a first treatment. All cases presented to our institution on day 11th following the injury. One was performed amputation on day 71st after injury.

Methods: All cases received standart antibiotic treatment as well as 3 days hospital observation. At first, no surgery were performed in any case. Regular wound evaluation and rehabilitation then managed in outpatient basis. On day 71st, amputation of 3rd and 4th finger was performed on one patient.

Results: All cases showed remarkable improvements of wound epithelialization, resolution of edema, range of motion, and general condition. Demarcation of any devitalized tissue showed clear margination during the period of observation. Such a condition were found in one of the case which showed prominent necrotic part on his $3 \mathrm{rd}$ and 4 th finger. Hence, we perform debridement and amputation of 3rd and 4th finger.

Conclusions: Although frostbite is rare in tropical countries, it may happen in particular those who partake in extreme cold activity such as mountain climbing and winter sports. Prevention and the right management will ensure a good outcome. After an appropriate conservative management at the onset, surgeons must opt for surgical management provided the demarcation of the wound becomes clear. Long-term follow-up management is necessary to achieve a good functional outcome. Preservation and if necessary reconstruction of the finger should become a priority in the patient management.
$\mathrm{F}$ rostbite is the most common cold injury in mountaineering and is frequently seen in high altitude climbers ${ }^{1}$. Frostbite is a thermal injury and the clinical features of frostbite relate to the initial freezing and the subsequent thawing of tissue, and the severity is dependent upon the temperature and duration of exposure ${ }^{2}$. Injury due to cold may be general or local. Local cold injury may occur at temperatures above freezing (wetcold conditions), as in immersion or trench foot. At temperatures below freezing (dry-cold conditions), frost bite occurs; the tissues freeze and ice crystals form in between the cells ${ }^{3}$. Local cold injury may or may not be associated with hypothermia. Although frost

Disclosure: The authors herely declare they have no financial interest in the information discussed in this article bite is the most common cold injury4, in civilian life, frost bite is uncommon despite populations of about 100 million at risk in areas where sub-zero temperatures occur at some period of the year ${ }^{3}$. Among mountaineers at high altitude this cases still occur regularly 4 .

Frostbite is a thermal injury and the clinical features of frostbite related to the initial freezing and the subsequent thawing of tissue, and the severity is dependent upon the temperature and duration of exposure. The wide spectrum of injuries observed range from minimal tissue loss and mild long-term sequelae, to extensive necrosis and subsequent amputation. Such severe injuries can have devastating consequences in young, otherwise fit individuals ${ }^{2}$. 


\section{Clinical Presentation and Classification}

\section{Symptoms}

Patients initially describe a cold numbness with accompanying sensory loss ${ }^{2}$. The extremity feels cold to touch and it feels clumsy, "like a block of wood". Thawing and reperfusion is often intensely painful and pain may persist for weeks or months, even after tissue demarcation. Residual tingling sensation starting after one week has been described and may be due to an ischaemic neuritis ${ }^{7}$. Symptoms are exacerbated by warm environments. Other sensory deficits include spontaneous burning and electric current-like sensations and may persist for years after the initial injury².

\section{Signs}

Initial appearances are often deceptively benign. However with thawing, frozen tissue may appear mottled blue, yellowish-white or waxy. Following rapid rewarming, there is an initial hyperemia even in severe cases, often with a purplish discoloration ${ }^{2}$.

\section{Classification}

Frostbite injury has been classified as either mild/superficial (no tissue loss) or severe/deep (with loss of tissue) ${ }^{2}$, and this classification is based upon final outcome (Table 1). Cauchy et $\mathrm{al}^{8}$ proposed a predictive classification system that is based on the topography of the lesion(s) and early 99 technetium bone scanning. Using these techniques it is now possible accurately to predict the likely outcome as early as two days (Table 2).

\section{Frostnip}

Skin becomes white and loses sensation. On rewarming becomes hyperemic and paraesthetic. Recovers completely. paraesthesia persists for some weeks.

Cauchy et al proposed a new classification of frostbite lesions involving the extremities and is based upon findings after initial rewarming and on day 2 after admission. Parameters a) initial lesion on day 0 after rapid rewarming, b) radiotracer uptake in bone scan on day 2, c) skin blisters on day ${ }^{2}$.

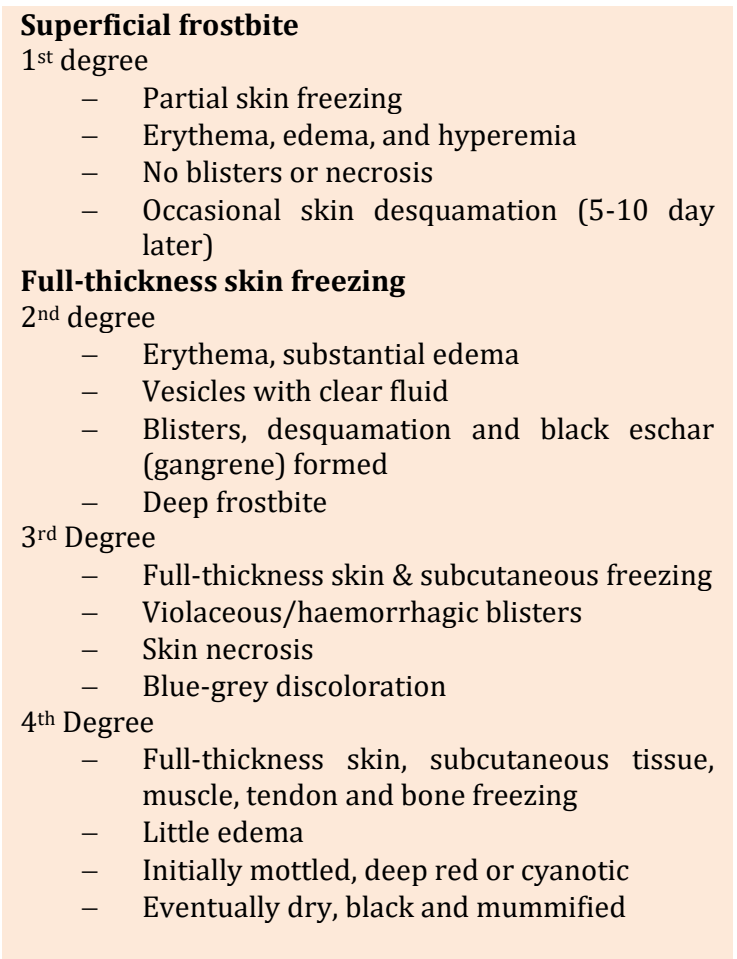

Maintenance of the central core temperature is essential to life and this may be carried out at the expense of the peripheral expendable structures such as the toes and fingers3. Cold damages tissues through cellular injury and vascular impairment. Cellular injury may be due to intracellular water crystallization, temperature-induced protein changes and membrane damage ${ }^{5}$ Vasoconstriction, endothelial injury and thromboembolism contribute to vascular insufficiency and ischemia. Overtime, necrosis and gangrene becomes apparent ${ }^{1}$. Mummification and autoamputation may occur'.

\section{Case Presentation}

We report 3 adults who suffered frostbite of the hand and face following Mount Denali Expedition (6192 meters above sea level) in early June 2017. At the summit (6192 
m) 2 patient felt extremely cold. When they took off his gloves to take pictures, they felt even colder and had severe pain in all of their fingers. They was shivering and had numbness and tingling in his extremities. They also felt fatigued with loss of appetite and they drank very little fluid. By the time they descended to base camp, they had swelling of the fingers with darkening of the skin of some of his fingers. They also got reddish on his nose and cheek Gradually, the swelling in the fingers turned into blisters, some of which ruptured spontaneously.

Table 1: Classification of cold injury according to severity ${ }^{2}$

\begin{tabular}{|c|c|c|c|}
\hline $\begin{array}{c}\text { Initial } \\
\text { lesion }\end{array}$ & $\begin{array}{c}\text { Radiotracer } \\
\text { uptake on } \\
\text { bone scan }\end{array}$ & Skin blisters & Grade \\
\hline None & $\begin{array}{c}\text { Not } \\
\text { indicated }\end{array}$ & None & 1 \\
\hline $\begin{array}{c}\text { Distal } \\
\text { phalanx }\end{array}$ & $\begin{array}{c}\text { Hypo- } \\
\text { fixation of } \\
\text { radiotracer }\end{array}$ & Clear fluid & 2 \\
\hline $\begin{array}{c}\text { Middle } \\
\text { phalanx }\end{array}$ & $\begin{array}{c}\text { Absence of } \\
\text { uptake on } \\
\text { digits }\end{array}$ & $\begin{array}{c}\text { Haemorrhagic } \\
\text { on digits }\end{array}$ & 3 \\
\hline $\begin{array}{c}\text { Carpal } \\
\text { or tarsal }\end{array}$ & $\begin{array}{c}\text { Absence of } \\
\text { uptake on } \\
\text { carpal/tarsal }\end{array}$ & $\begin{array}{c}\text { Haemorrhagic } \\
\text { on } \\
\text { carpal/tarsal }\end{array}$ & 4 \\
\hline
\end{tabular}

Table 2: Cauchy predictive classification of frostbite ${ }^{8}$

\begin{tabular}{|c|l|}
\hline Grade & \multicolumn{1}{|c|}{ Outcome } \\
\hline 1 & No amputation, no long term sequelae \\
\hline 2 & $\begin{array}{l}\text { Soft tissue amputation with fingernail } \\
\text { sequelae }\end{array}$ \\
\hline 3 & $\begin{array}{l}\text { Bone amputation on digit. Functional } \\
\text { sequelae }\end{array}$ \\
\hline 4 & $\begin{array}{l}\text { More extensive amputation, may develop } \\
\text { thrombosis or sepsis. Functional sequelae }\end{array}$ \\
\hline
\end{tabular}

One patient stays in the basecamp got his nose slightly swollen and turn darker with painful on touch. He got no blister nor swollen finger.

When the two climber reached base camp, their hands and feet had already thawed spontaneously. The patients get rewarming as first treatment. Povidone-iodine dressing was applied and sent to local clinics by helicopter. On the local clinic the patients is given Silver sulfadiazine dressing on is fingers and tetanus toxoid injection was given. Blistered areas were not debrided. they was given analgesics and the patient go back to Indonesia.
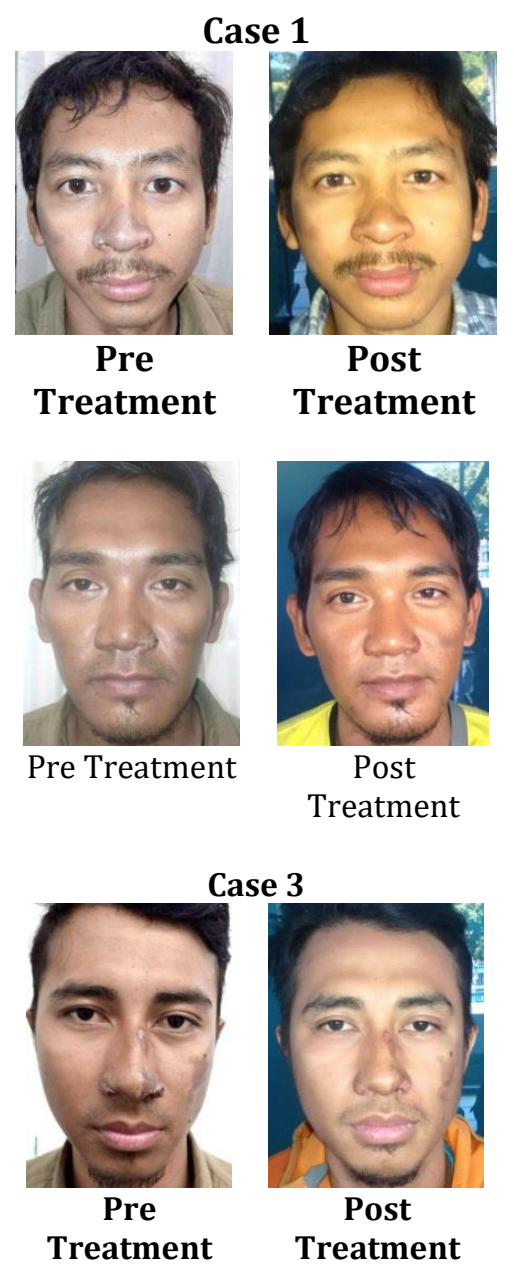

On day 11th after injury the patient arrived at our hospital, the first patients finger was turning to black on the distal phalanx and have some blister on his right hand. his nose got dark colored but his does not feel pain, the sensation is a little decreased.

The second patient got blister both of his hand and dark colored nose with decreased sensation on his nose. The finger is painful to touch. The third patient (who doesn't go to the summit) got blacked nose with decreased sensation. 
After 3 days of intravenous antibiotics administration, the patient treated as outpatient and have routine follow up for regular wound evaluation and rehabilitation.

The first patient got his 3rd and 4th finger getting darked and mumificated. On day 71 st after injury, the patient performed amputation. The dark coloured nose is faded and barely seen, and the sensation turned to normal.

The second patient got his finger turned to normal, the necrotic skin debrided and we found there already epithelialization underneath it. Although the still feel tingling sensation on touch. The nose is getting normal, with improved sensations.

Maintenance of the central core temperature is essential to life and this may be carried out at the expense of the peripheral expendable structures such as the toes and fingers 3 . Cold damages tissues through cellular injury and vascular impairment. Cellular injury may be due to intracellular water crystallization, temperature-induced protein changes and membrane damage ${ }^{5}$ Vasoconstriction, endothelial injury and thromboembolism contribute to vascular insufficiency and ischemia. Overtime, necrosis and gangrene becomes apparent1. Mummification and autoamputation may occur 6 .

The third patient blacked nose is turned to normal, the necrotic skin was debrided and the epithelialization was formed underneath it. The sensation was turn to normal.

\section{Discussion}

Frost bite is the most common cold injury4. Extremities are most commonly affected 9. One of the major groups at risk of frostbite is mountaineers, who are mostly affected in cold seasons and at high altitudes. Frostbite occurs when unprotected tissue is exposed to temperatures well below freezing even for relatively short periods ${ }^{10}$. The tissues in the affected areas freeze. Ice crystals form intracellulary (if freezing is very rapid) or in the intracellular space. This results in water being drawn out of the cell, causing cell damage. Concurrently, there is slowing of blood flow in the affected area, eventually leading to thrombosis and to tissue ischemia?

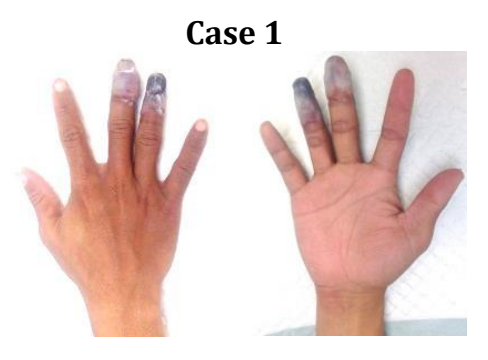

Pre Treatment
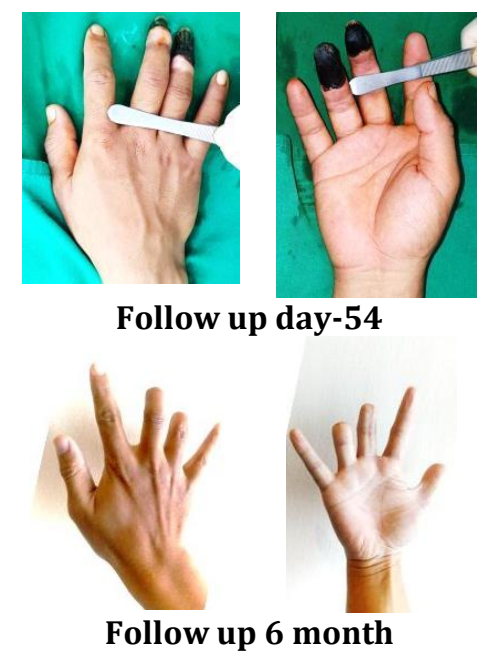

Figure 2. Case 1. Finger follow up after treatment.

From the clinical view point it is classified into four degrees of progressive injury identified by physical signs and the following sequelae ${ }^{11,12}$. First degree injury is characterized by epidermal involvement, which causes erythma, mild edema, and sequelae over the next few weeks such as desquamation and cold sensitivity. Second degree injury is full thickness skin freezing with substantial edema and formation of clear blisters, which contract and dry within two to three weeks, forming a dark eschar. Third degree injury is characterized by formation of hemorrhagic blisters, blue-grey discolouration of the skin, deep burning pain or rewarming, thick gangrene eschar formation. In fourth degree injury, muscle, bone and tendons are involved. Our patient had probably sustained a fourth degree frost bite injury which had sequentially led to 
autoamputation of distal portion of her feet over time ${ }^{13}$.

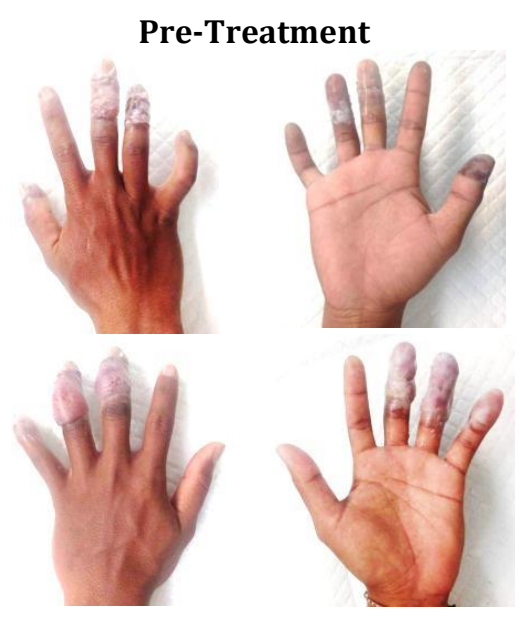

Follow up 6 month
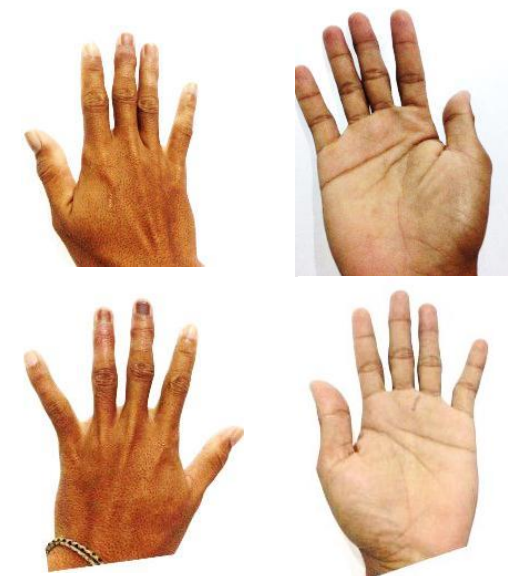

Figure 3. Case 2. Finger follow up after 6 month.

Factors that contribute to frostbite include hypothermia, inadequate clothing, wet clothes, wind chill, and dehydration from increased metabolic activity associated with climbing1,10.

In addition, fluid loss, inadequate intake of water, hypoxia due to high altitude, and poor circulation from any cause, such as tight boots, increase the risk of frostbite. Certain medications, smoking, alcohol use, or any systemic or local disease affecting blood vessels may also predispose to frostbite7,10.
Initial treatment of frostbite is rapid rewarming of the frozen tissue by submersion in warm water at $37^{\circ} \mathrm{C}$ to $39^{\circ} \mathrm{C}$ (just above body temperature) until return of circulation, usually about 15 to 30 minutes. High temperature thawing may be deleterious. Thawing and subsequent refreezing can cause devastating tissue injuries ${ }^{14,15}$.

Two main reactions take place when tissues come into contact with a very cold object. Firstly, a vascular reaction occurs under the frozen superficial tissues consisting of damage to the wall of the blood vessels, leakage of plasma into the tissues (forming blisters), and an increased viscosity of the remaining intravascular blood, with local hemoconcentration or "sludging." The small vessels may thus become blocked. If the blood flow is then stopped by the action of the precapillary sphincters, the arteriovenous shunts will open up and blood bypasses the frozen area, which becomes avascular: in other words, the diseased part is sacrificed for survival of the whole organism ${ }^{13}$.

The second reaction is the formation of intercellular ice crystals. The intracellular osmotic pressure rises and enzyme mechanisms are disturbed with subsequent cell death ${ }^{3}$. A layering system, which creates a microclimate around the body protecting against cold and wind, is highly efficient in preventing frost bite and hypothermia4. Management of such cases demands attention to hypothermia and local cold-induced injury as well as to coexisting trauma, infection and intoxication if any. In the prehospital care of frost bite, nonadherent wet clothing should be removed. Local rewarming started. In hospital, rapid rewarming of a frost bitten extremity in a bath of water between $40^{\circ} \mathrm{C}$ and $42^{\circ} \mathrm{C}$ for 15 to 30 minutes may minimize tissue loss ${ }^{16}$. Splinting and elevation of affected part reduce edema and improve perfusion. Hospital stay for patients with deep frost bite is often prolonged. Surgical amputation may be required many weeks after the injury 4 .

Aloe vera dressing, wrapping, and elevation of the frostbitten extremities are often recommended. Aloe vera may aid healing of frostbite ${ }^{17}$. Tetanus prophylaxis and 
analgesics are routinely recommended ${ }^{7,15}$. Antibiotics are not routinely prescribed for all cases of frostbite. However, we decided to use antibiotics, since we suspected localized infection. Use of thrombolytic therapy, either locally or systematically, shows promise. It may improve tissue perfusion and reduce amputations ${ }^{14,15}$. There are claims that hyperbaric oxygen may improve blood flow in frostbitten areas more than 2 weeks after the injury ${ }^{7,10}$.

Debridement of necrotic tissues is generally delayed until there is a clear demarcation from viable tissues, a process that may take up to 3 months. Surgical intervention is reserved mainly for late treatment of frostbite or when guided by advanced imaging such as triple-phase bone scanning or magnetic resonance imaging $7,14,15$. Even brief exposure to cold, as in our case where the climbers took off their gloves at the summit, can cause frostbite. Those who recognize these problems and take preventive measures like drinking adequate fluids, wearing warm protective clothing, and using supplemental oxygen for mountain climbing are less likely to suffer from frostbite ${ }^{7,10}$.

Simple steps to prevent hypothermia, hypoxia, and dehydration can benefit any climber at high altitude. Fortunately, our patient did not suffer any major sequelae of frostbite ${ }^{18}$.

\section{Reference}

1. Harirchi I, Arvin A, Vash JH, Zafarmand V. Frostbite: Incidence and predisposing factors in mountaineers. $\mathrm{Br} \mathrm{J}$ Sports Med. 2005;39:898-901.

2. Grieve, A.W., Davis, P., Dhillon, S., Richards, P., Hillebrandt, D., Imray, C.. A Clinical Review of the Management of Frostbite. J R Army Med Corps 157(1): 73-78.

3. Ward M: Frostbite. Br Med J 1974, 1(5897):67-70.

4. Harirchi I, Arvin A,. Vash JH, Zafarmand V: Frostbite: Incidence and predisposing factors in mountaineers. British Journal of Sports Medicine 2005, 39:898-901.

5. Heggers JP, Robson MC, Manavalen K, Weingarten MD, Carethers JM, Boertman JA, et al.: Experimental and clinical observations on frostbite. Ann Emerg Med 1987, 16:1056-62.

6. Biem J, Koehncke N, Classen D, Dosman J: At the Bedside Out of the cold: management of hypothermia and frostbite. CMAJ 2003, 168(3):305-311.

7. McCauley R L, Smith D J, Robson M C, Heggers J P. Frostbite. In Wilderness Medicine by Auerbach P S. Mosby 2001 (4 th ed).

8. Cauchy E, Chetaille E, Marchand V, Marsigny B. Retrospective study of 70 cases of severe frostbite lesions: a proposed new classification scheme. Wild Env Med 2001;12:248-255.

9. Crismon JM, Fuhrman FA: Studies on gangrene following cold injury: vi. Capillary blood flow after cold injury, the effects of rapid warming, and sympathetic block. J Clin Invest 1947, 26(3):468-75.

10. Epstein Y, Moran DS. Extremes of temperature and hydration. In: Keystone JS, Kozarsky PE, Freedman DO, Nothdurft HD, Connor BA, eds. Travel Medicine. Philadelphia: Mosby; 2004:383-392.

11. Reamy BV: Frostbite: review and current concepts. J Am Board Fam Pract 1998, 11:3440.

12. Zonnoor D. Frostbite. [http://master.emedicine.com/ped/topic803 .htm]. accessed 26th May 2018

13. Wani, A. H., Mohsin, M., Darzi, M. A., Zaroo, M. I., Bashir, S. A., Zargar, H. R., Rasool, A., Bijli, M. A. Dar, H., Farooq P. O., and Ahmed, S. T. An unusual case of frost bite autoamputation of toes. Cases Journal 2008, 1:398.

14. Bruen KJ, Gowski WF. Treatment of digital frostbite: current concepts. J Hand Surg. 2009;34:553-554.

15. Roche-Nagle G, Murphy D, Collins A, et al. Frostbite: management options. Eur J Emerg Med. 2008;15:173-175.

16. Britt LD, Dascombe WH, Rodriguez A: New horizons in management of hypothermia and frostbite injury. Surg Clin North Am 1991, 71:345-70.

17. Miller MB, Koltai PJ. Treatment of experimental frostbite with pentoxifylline and aloe vera cream. Arch Otolaryngol Head Neck Surg. 1995;121:678-80.

18. Subedi, B.H., Pokharel, J., Thapa, R., Banskota, N., Basnyat, B.. Frostbite in a Sherpa. Wilderness \& Environmental Medicine, 21, 127-129 (2010) 